\title{
A Laboratory for Manufacturers
}

\section{A German Scientific Institution That Tests a Manufacturer's Raw Material and Products and Gives Him Scientific Advice}

\section{By Waldemar Kaempffert}

THIS is the first of a series of articles intended to 1 show the part that science plays in German industry and commerce. The author of the article, Managing Iiditor of the SCIENTIFIC AMERICAN, was sent to Europe by the publishers to study German industrial conditions with this object in view.

A Saxon manufacturer of silk cravats found that his orders were steadily diminishing, although the season and the market were both in his favor. $\mathrm{He}$ made an investigation and discovered that his customers were buying silk cravats from a Prussian manufacturer at a price fifty per cent less than that at which he could produce them. To the Saxon's eye and touch the cheaper cravats were as good as his own. He could detect nothing in the material that could explain why cravats exactly the same in appearance should be sold at two widely different prices. He spent a month in thoroughly overhauling his factory. $\mathrm{He}$ found that he was buying his raw material at the lowest possible prices; that his wages were not higher than they should be; that his overhead charges were not excessive, and that his organization was good. Yet the fact remained that the Prussian was underselling him and was apparently making money.

The Saxon was an expert in cravats-at least he thought he knew all about them, because he had been making them for the better part of his career. Yet for the life of him he could not explain why it was impossible for him to compete with the Prussian. One day a salesman of his suggested that it might be well to have the Saxon and the Prussian cravats scientifically compared by the Koenigliches Material-Pruefungsamt-the Royal Laboratory for Testing Materials at Gross Lichterfelde, near Berlin. The examination would cost but little and might explain the mystery. $A$ s a manufacturer, the Saxon was convinced that he knew more about cravats than any scientist in any government testing laboratory, and that his trained eye and his sensitive thumb were more to be relied upon than lenses and chemicals. Still he consented. Samples of the Prussian and Saxon cravats were sent to Gross Lichterfelde. Two weeks later he received a formal report. His own cravats were pure silk. The Prussian's cravats were half genuine silk and half artificial silk (nitro cellulose). $\Lambda$ chemist and a microscopist, neither of whom had ever made a cravat in his life, had not only discovered in an hour or two a deception that a manufacturing experience of thirty years had failed to "note, but even revealed what particular process had been used in making the artificial silk employed.

The Technical Problems of Commerce.

It would not be difficult to relate a hundred instances such as this, all of them typical of the work done at the most remarkable testing laboratory in the world. At Gross Lichterfelde I saw not only cravats undergoing a rigorous scientific investigation, but chains, rirders, paper, textiles, wood, dyes, copper, rubber ink, typewriter ribbons-almost every kind of materia that is used in our daily lives. Sometimes, as in the case of the Saxon of the Saxon manufacturer of cravats, the manufacfound himself with oxidized metal or faded goods on his hands, unable to discover the cause of the defects sometimes he thought the customs officers had wrongly appraised his importations, because they had misjudged the character of the material; sometimes he wanted to know which of several raw materials should he employed for a specific purpose and was unable to decide himself.

The Royal Laboratory for Testing Materials works hand in hand with the German industrial For a sum of money that must seem slight to Americans it places at his command a staff of two hundred and twenty-two men, seventy-two of whom are technically trained and the highest authorities in their respective departments of science. These men have at their disposal an equipment that includes the best obtainable apparatus for testing and analyzing any given material.

In Germany, indeed in Europe, the Laboratory is regarcled as a court of last resort in matters involving the application of science to business. It is frequently difficult for a scientific man in the employ of a large corporation to deliver an absolutely impartial opinion on his firm's product. Inevitably there is a tendency to underestimate the products of a rival manufacturer and to view his own with favor. There is no such tendency in the Royal Testing Laboratory. is no such tendency in the Royal Testing Laboratory.
Every chemist every engineer, every microscopist, every physicist, is a government official, and, as such, he is enabled to assume an absolutely impartial and judicial attitude toward the problem given him for solution. Indeed, impartiality is insisted upon, not only in the testing and examination of materials, but also in the phrasing of the reports submitted to an applicant for information. The manufacturer who can use one of the Royal Testing Laboratory's colorless opinions for acivertising purposes would be miraculously inenious. To restrain him, however, from exercising too freely what average ingenuity Nature has endowed him, and to prevent him from quotıng with approval a report which is many years old and not at all applicable to his present goods, the Director of the Laboratory refuses to furnish certified copies of opinions more than one year old, and sometimes goes to the trouble of checking up advertisements in which reference is made to the favorable opinion of the Royal Testing Laboratory.

Scientists Who Study Factory Methods in Factories.

In order that the Laboratory may keep in close touch with industrial developments, members of its staff are sent from time to time to factories in order to study the exact manner in which textiles, cement, paper, ink, elaborate the equipment for testing caoutchouc and elaborate the equipment for testing caoutchouc and
electric insulators, the exact manner in which rubber goods are made industrially was carefully studied, so that machinery could be designed which would enable a chemist or physicist to determine those facts which would be most useful to a rubber manufacturer. What manufacturer, for example, can tell definitely whether or not rubber goods should be stored in moist or dry rooms; whether that room may be indifferently hot or cold, dark or light; whether a rubber strip should be stored stretched or unstretched? These and simila questions Gross Lichterfelde will soon answer for him definitely, as the result of a long series of most practical experiments.

German manufacturers have not been slow to recos nize the immense value of a government laboratory which solves for them the technical problems of conmerce. A number of manufacturers of electric insulat ing materials jointly supplied the necessary funds for a painstaking study of insulating materials and of the insulating properties of rubber substitutes. The many compositions submitted were tested at various temperatures to determine their readiness of manipulatio in the factory, their behavior under tension, torsion, and traction; their hardness; their ability to withstand exposure to weather and chemical corrosives. When the results of these studies are published. the Society of German Electro-Technicians will frame specifications for electric insulating materials, in which for the first time some admirable substitutes for rubber will receive their due.

How very impartial is the attitude assumed by the Laboratory is apparent when it is considered that manufacturers of competing materials may appeal fo scientific information to Gross Lichterfelde at the sam time. Sand-lime brick and clay brick are competitiv building materials. Yet a powerful association of sandlime brick manufacturers and an equally powerful association of clay brick manufacturers simultaneously consulted Gross Lichterfelde for the purpose of improving their respective bricks. The comparative test which were made proved immensely valuable to bot associations and gave the ultimate consumer a far better building material than he would otherwise have been able to purchase.

Perhaps the Laboratory has done its most efficient work in co-operation with the technical associations of Germany-associations of engineers, manufacturers an technical men. Thus in conjunction with the Societ of German Cement Manufacturers, the Laboratory conducted an exhaustive investigation which has resulted in a scientific standardization of Portland cement. and has definitely settled such nice points as the influence of high temperature on concrete, the effect of copper, lead and zinc on cement, and the comparative merits of Portland cement and iron slag Portland cement. Similarly, in co-operation with the Society of German Bridge and Structural Iron Builders, a painstaking study of the strength of rivets in stee girders was made.

\section{A Study of Paper and Ink.} It must not be supposed that all German manufac-
turers have been broad-minded enough to submit their products to Gross Lichterfelde for approval. An attempt to analyze the various kinds of automobile gasoline sold throughout the German Empire, and to induce the wholesale dealers in gasoline to standardize liquid tuel so that the motor car owner could buy gassoline in Southern Germany exactly similar in quality to that sold in Northern Germany, was met by a flat refusal on the part of the dealers to assist the Laboratory. It is only a question of time when the Laboratory will succeed in carrying out its plan. Simlar opposition was encountered when Gross Lichterfelde was commissioned by the government to analyze German papers and to determine their availability for bank notes, public documents and the like, an opposition that may be understood when it was discovered that only a very small percentage of German papers were found to answer the government's requirements. $A \mathrm{~s}$ the result of the work done at Gross Lichterfelde, the German paper manufacturer has so far improved his product that rarely indeed has he failed to fulfill government conditions. Opposition to the scientific investigations of the Laboratory has given place to the heartiest co-operation.

It was but natural that after paper was studied for the government the thousand and one inks sold in the German market should have been carefully analyzed and tested to determine their chemical composition and their ability to withstand light, fire, and weather. That investigation has only recently been completed. 'The government can now specify with scientific precision the characteristics of a wellnigh perfect ink to be used on its wellnigh perfect paper.

The standardization of manufactures is thus undertaken only for the government. The Laboratory, as a government institution entrusted with the scientific examination of material used by the government, can dictate the requirements which that material must fuliill; but it would not set up standards for the manufacture of articles for ordinary consumption. When a manufacturer requested the Laboratory to determine for him the qualifications that an asphalt should have for in sulating purposes, he was told that the asphalt industry must frame its own standards, but that the Laboratory would assist him by giving scientific advice.

\section{A Scientific Court of Last Resort in Technical Disputes.}

As an impartial institution for scientifically passing upon the commercial availability of manufactured products, Gross Lichterfelde is required by law, when requested to do so, to settle technical disputes. In stead of wasting time and money in asking the courts to decide whether or not a contract has been carried out according to the spirit and the letter, the disputants often submit their case voluntarily to the Laboratory for decision. A builder ordered a large quantity of roofing tiles and specified that they were to be waterproof. When the tiles were delivered he refused to pay for them on the ground that they failed to comply with the conditions of the contract. The dispute was submitted to the Laboratory for decision. The tiles were tested and it was found that thev were sufficiently waterproof to come within the meaning of the contract.

Even if a case does go to court, the Laboratory may be asked by the presiding judge to decide the technical point at issue. The decision is binding upon both sides - a veritable boon to a court confronted with a mass of conflicting expert testimony. In one case it appeared that in the construction of a wall a stone composed of crushed slag had been employed together with lime mortar. The mortar failed to harden. The dealer who had delivered the slag stane insisted that the wrong kind of mortar had been employed. The mortar maker retorted that the slag stone was worthless. The experts summoned by both sides failing to agree, as might be supposed, the court submitted the whole matter to Gross Lichterfelde. There it was decided that the mortar had failed to harden, not because it had been made with the wrong kind of sand (as one expert had declared) nor because the slag was of the wrong kind (as another expert had insisted), but because many lime mortars harden only when exposed to the air, and then only after they have been alternately moistened and dried. Hence, said Gross Lichterfelde, the core of a wall, as in the case in question, is not likely to harden at all, whether or not a slag stone or good rick is employed.

In another case the court called upon the Laboratory (Continued on page 60: 
Retrospect of the Year 1911 hovered for ave minutes above a given
spot. Mr. Wright obtained valuable intempted to fly from Key west to Havana. formation relative to the designing of a After covering ninety miles out of the one hundred in two hours, he fell in the sea owing to a burned-out bearing on his motor. Mr. Glenn Curtiss first succeeded in rising from the water, with his biplan efruipped with floats, at san
January 26th. Thus was born America:s first hydro-aeroplane. Curtiss constructwhich have been supplied to our navy and one to that of Russia, which is very actone to that of Russia, which is very act-
ive in aviation. Using one of them, Hugh ive in aviation. Using one of them, Hugh
Lobinson flew several hundred miles down the Mississippi from Minneapolis, carrying mail, which he left at the towns en route. The mail-carrying experiments
made on a larger scale at the aviation made on a larger scale at the aviation
meet at Nassau Boulevard, together with meet at Nassau Boulevard, together with
Lobinson's demonstration, convinced I'ostmaster-General Hitcheock that the aero-
plane can be used successfully for de!irplane can be used successfully for de!ivering mail to inaccessible places. Many
exhibition flights have been made in exhibition flights have been made in
America this year, the most daring and thrilling of all having been Lincoln Beachy's dip over Niagara Falls and fight

through the gorge, which he

The chief development in aviation this year has been the change from the exhibition fiight to the long-distance, crossraces, such as the Paris-Madrid, l'arisRome, European Circuit, Circuit of Britain, etc., were flown successfully abroad and were practically all won by monosafer than the biplanes. In America, however, Beachy and Ely gave some marvelous exhibitions of flying in strong winds with the latter type of machine. A Maurice Farman biplane, on March 7th, made the 225-mile fight from Paris to the Puycarrying two men. Eugene Reneaux, the carrying two men. Eugene Reneaux, the
pilot, thus won the Michelin $\$ 20,000$ prize pilot, thus won the Michelin $\$ 20,000$ prize
which had been offered exactly three years before. Vedrines, on a Morane
monoplane, won the Paris-Madrid race monoplane, won the Paris-Madrid race and secured second place in the 1,060-mile
Circuit of Britain. This English event, Circuit of Britain. This English event, as: well as the Paris-some and the European circuit, was won by Lieut. Conneau, was second in the two latter races. Both of these aviators used Blériot monoplanes. The Paris-Madrin race of 900 miles was Britain required but three days' flying by Conneau and Vedrines. The two other machines which finished required thir-
teen and fourteen days respectively. $M$. teen and fourteen days respectively. M.
Garros, on September 4 th, made a new leeight record of 4,252 meters $(13.950$ feet), thus beating by 2,370 feet the record of Beachy at Chicago, and climbing
some 750 feet more than $21 / 2$ miles above some 750 feet more
the earth's surface.

the earth's surface.
Last summer, Harry N. Atwood flew from Boston to Washington with his Wright biplane, carrying a passenger most of the way. Later, he flew from St. Louis to New York, by way of Chicago, attempt a flight this year; but it is prob-
in fourteen days. Enthusiastic over his able that next spring both will start in success, Calbraith P. Rodgers and Robert this that next spring both will start in G. Fowler started to fly across the con-l his experience with the "America" tinent from New York and San Fran- 1910, has constructed a new and large cisco respectively. Both aviators used airship, from which he believes he has by special trains, carrying spare parts. previous failure.

After three unsuccessful attempts at climbing over the Sierra Nevada Moun tains, Fowler finally flew by the southern route, which was the one chosen by
Rodgers. Rodgers left Sheepshead Bay on September 17 th. His route was via

A Dark Substance in Space $\mathrm{N}$ the vicinity of the star $\mathrm{S}$ Coron
Australis Innes and Worsell hav
found a patch of sky 25 minutes of ar Chicago, St. Louis, San Antonio, and Isl in diameter where no star can be see
Paso, Texas, from which State he for-
lowed the Southern lacific Railroad. He with a 9-inch refracting telescope. Ac
cording to Innes, who discusses the subfowally reached I'asadena on November cording to Innes, who discusses the sub5th. In flying the 25 miles from there ject in "Transvaal Observatory Circular to the Pacific Ocean, he sustained a bad No. 5," the apparent absence of stars in fall and was laid up several weeks. this region is due to the occurrence of Finally, on December 10th, he finished
the first trans-continental aeroplane flight the first trans-continental aeroplane flight. He passed Fowler at Tucson, Ariz, and
the latter has now progressed almost as

the latter has now 1 .
far as New Orleans.

Orville Wright conducted some experiments with a 145-pound glider at Kitty Hawk, N. C, late in Uctober. These exfact that $\mathrm{Mr}$. Wright succeeded in rising for on the supposition that the absorbin the teeth of a 50-mile gale and remain- of the star, but has since withdrawn ing aloft once for $7 \frac{1}{4}$ minutes, and again from it.
The Most Remarkable Testing Laboratory in the World (Concluded from page 585.) to decide whether or not a certain lubri cant had spoiled a suit of clothes. The judge washed his hands of the matter and submitted the lubricant to the Royal Laboratory for Testing Materials. With characteristic thoroughness the Laboratory experimented with stains which it determined whether the stains could be eradicated by washing or only wit Then it determined whether the color of the cloth had suffered as the result of attempting to remove the stains. Finally it ascertained whether the strength of the cloth fiber had been impaired by the process of cleaning. It reported to the court that stains made with the lubricant on cotton, wool and linen could be no injurious effect on the dyes employed, and that the lubricant did not weaken the fiber, even after prolonged intimat contact-in a word, that
not irretrievably spoiled.

Settling Patent Infringement Suits.

In patent infringement suits, as might expected, the Laboratory does yeoman service for the court. It does not construe claims, for that is a matter of law; but it determines matters of technic
fact, with the result that a judge fact, with the result that a judge is spared the necessity of considering a mass of testimony which, to a layman in sci ence, even though he be a lawyer, must
seem a hopeless jumble of cryptic phrases. One such case turned upon the point whether or not a certain brand of soap was so greatly superior to another i
washing qualities as to be patentably different. On behalf of the court, the Laboratory made a study of the two soaps to oratory made a study of the two soaps to
determine their solubility in water, acids and lime solutions, and their effect on dyes and on fabrics. It showed conclusively that the one soap was no bette The other.

These opinions of the Laboratory on matters of technical fact are by law made
binding upon the courts. $A$ judge must binding upon the courts. A judge must
accept the technical decision of the Labo-

accept the technical decision
ratory and rule accordingly.

Germany has a tariff, which, like our own, is intended to protect the home producer. Disputes with the customs au Germany as in the United States. Th Imerican appraiser submits imported
goods for scientific examination either to chemists or physicists in the employ of the customs service, or else he employ authorities call upon the Royal Laboratory for Testing Materials for assistance In a controversy which arose between th customs authorities and an importer of
mercerized cotton, the government maintained that the fabric was dyed and therefore subject to a higher duty than
if it were undyed. The importer insisted that the cotton was undyed. Gros Lichterfelde examined the fabric scie
tifically and supported him in his co tifically
tention.

An American Appeals for Scientific Help. Foreigners, too, resort occasionally he Laboratory when the questions a an American importer of German told who had been compelled, as he thought to pay a higher duty in the United States cause the importation was an oily man paper substitute for parchment. $h$ asked the Laboratory to tell him how treated papers could be scientifically dis tinguished from untreated papers. II received an exhaustive description of the turpentine oil test, armed with which h intended to appeal to the American customs authorities again. Another foreign
firm wished to ascertain whether its stee hydrogen flasks met the requirements of the German police regulations governing the traffic in liquid and compressed gases
Flasks were sent to Gross Lichterfelde There it was found that the wrong kind of metal had been employed, and that the fulfilled.

Whenever any department of the German Imperial Government is confronted with a technical problem for solution it is (Concluded on page 604.)
PATENTS

\section{Patensers}

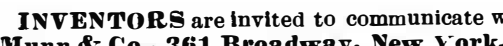
Iunn \& Co.. 361 Broadway, New York, o to securing vaiid patent protection for their Invent ious. Trade-Marks and Copyrights
registered. Design Patents and Foreign Patent ssecured.
A Free Opinion as to the probable patenta-
bility of an invention will be readily given to ans bility of an invention will be readily given to any
inventor furnishing us with a model or sketch and
a brief description of the derice in question. All a brief description of the device in question. All
communications are strictly conflential. Our request.
Ours is the Oldest agency for securing pat
it

MUNN \& C0., 36I Broadway, New York
Branch office. 625 F St.. Washington. D. c.

A T E N T S SECURED OR FEE Free report as to Patentability.
Bonk. and Wbat To Invent with List of Inven-
tions Wanted and Prizes offered for inventions
ree. VICTOR J. FV ANS \& CO.. Wasbington, D.C.

Classified Advertisements

than four nor more than 12 lines aceepted. Count
Reven words to the line. All orders must be accom-
panied by a remitiance.

AUTOMOBILES.

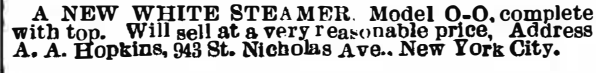

BUSINESS OPPORTUNITIES.

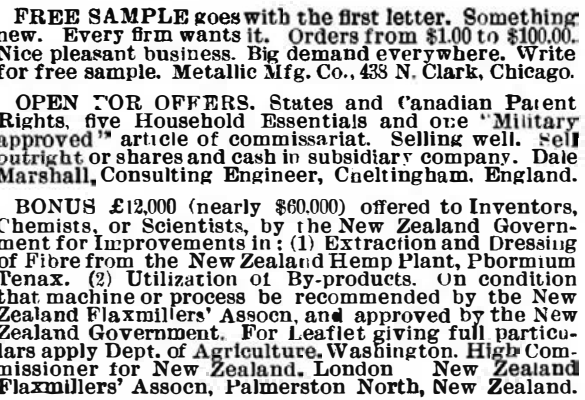

PATENTS FOR SALE.

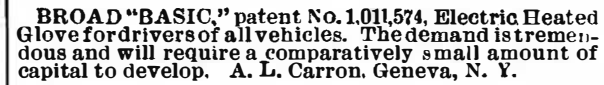

REAL ESTATE.

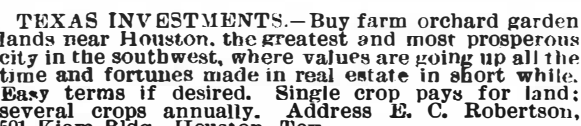

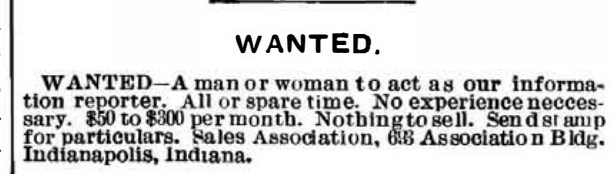

MISCELLANEOUS.

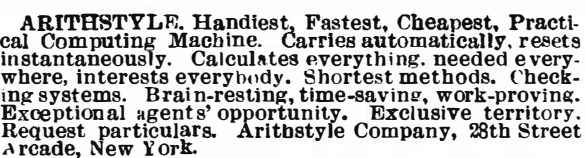

INQUIRY COLUM N READ THIS COLUMN CAR EFULLY.- Y ou will fin
iuquiries for certain ciasses of articles numbered in
consecutive order. If you manufacture these go rite us at ouce and we will send you rhe name and
address of the party desiring the inf firmation. There
is no charge for tbis service. In every case it is
necessary to give the number of the inguiry.

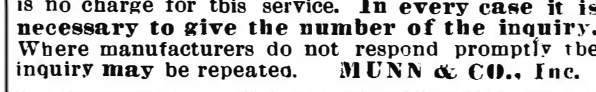

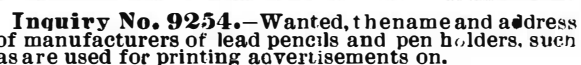
Inquiry No. 925.5. - Wanted. to buy a patent rol.
ler, a ball-bearng axle. - Which could be purchased on a
royalty basis; it must be cbean and fully proved. Inquiry Yo. 92.sts. Wantert addresses of parties
baving Pitchbleyde deposits, if able to ship ore. Inquiry No. 925. W. Wanted addresses of firms
selling second-hand water turbines. Inquiry No. 1258 . - Wanted addresses of parties.
having gem materials to ofer in ans part of the world.
Inquiry No. 295!).- Wanted to buy a machine for Inquiry No. 2959.- - Wanted to buy a machine for
removing the coating of a flbert. Inquiry No. 9260. - Want addresses of parties able
to sbip corrundum, garnet. Alint, emery or any material
sultable as anabrasive. Inquiry No. 9261. -Wanted, a manufacturer to
make card games Inquiry No. 926!2,-Wanted, to buy a glass which
is a cor: 1 ductor of electricity, and the address of $t$ be
makers of the same. 